\title{
Dehydroepiandrosterone inhibits DNA synthesis of rat hepatocytes induced by partial hepatectomy or mitogen (ciprofibrate)
}

\author{
M. S. Rao and V. Subbarao \\ Department of Pathology, Veterans Affairs Lakeside Medical Center and Northwestern University Medical \\ School, Chicago, USA
}

(Received 2 January 1997; revision accepted 4 March 1997)

\begin{abstract}
In a previous study we have shown that dehydroepiandrosterone (DHEA) inhibits hepatocyte DNA synthesis after short-term administration and induces hepatocellular carcinomas after long-term administration in the rat. It is not known whether DHEA is also capable of inhibiting replicative and mitogen-induced DNA synthesis. In the present study, we have evaluated the effect of DHEA on DNA synthesis in the rat liver after partial hepatectomy and mitogen administration. After partial hepatectomy, DHEA significantly inhibited DNA synthesis at 20, 26, 32 and $38 \mathrm{~h}$. Similarly, combined administration of ciprofibrate, a peroxisome proliferator and mitogen, and DHEA also resulted in significant hepatocyte DNA synthesis. However, DHEA did not affect liver enlargement caused by ciprofibrate. This experimental system will serve as useful tool to evaluate the role of cell proliferation in carcinogenesis.
\end{abstract}

Dehydroepiandrosterone (DHEA), a steroid hormone secreted by the adrenal cortex, has been shown to exert protective effect against several pathological processes including carcinogenesis in experimental animals (Schwartz et al. 1988, Nestler 1995). Although DHEA was proved to be anticarcinogenic in several tissues (Schwartz \& Pashko 1995), it has been shown to induce tumours in the rat liver (Rao et al. 1992b, Hayashi et al. 1994). Hepatocarcinogenic effect of DHEA was considered to be mediated through peroxisome proliferation and the resulting oxidative stress (Rao et al. 1992a). Interestingly, DHEA was shown to inhibit hepatocyte proliferation after dietary administration for 2 weeks. Based on these findings it was suggested that cell proliferation is not an essential factor in DHEA-induced hepatocarcinogenesis.

Under physiological conditions, in adult animals, hepatocytes rarely divide. However, hepatocytes can be easily stimulated to proliferate either after cell loss (compensatory hyperplasia) or after mitogen administration (direct hyperplasia). It is not known whether DHEA inhibits cell proliferation only under physiological conditions or after partial hepatectomy $(\mathrm{PH})$ and mitogen administration. The present experiment is designed to

Correspondence: M. S. Rao, Department of Pathology, Northwestern University Medical School, 303 E. Chicago Avenue, Chicago, IL 60611, USA. 
examine the effect of DHEA on cell proliferation induced by $\mathrm{PH}$ and administration of ciprofibrate, a peroxisome proliferator and mitogen.

\section{MATERIALS AND METHODS}

Male F-344 rats weighing 80-90g were purchased from Charles River Laboratories (Wilmington, MA), and housed in groups of four in plastic cages on San-i-cell bedding in an air-conditioned room with a $12 \mathrm{~h}$ dark and light cycle. Rats were fed Purina rat chow and had free access to water. After a week of acclimatization in the laboratory rats were divided into different groups.

DHEA acetate was purchased from Sigma chemical company (St Louis, MO). Ciprofibrate was a gift from Sterling-Winthrop Research Institute (Rensselaer, NY). Tritiated thymidine $\left[{ }^{3} \mathrm{H}\right] \mathrm{dT}$, specific activity $46 \mathrm{Ci} / \mathrm{mmole}$ was purchased from Research products international corporation (Mount Prospect, IL).

To evaluate the effect of DHEA on compensatory hyperplasia, 32 rats were divided into two equal groups of 16 each. One group was fed chow containing $0.45 \%$ DHEA for 7 days and then all rats were subjected to partial hepatectomy according to the procedure of Higgins \& Anderson (1931), in which approximately $65 \%$ of the liver was removed. The second group of rats were fed normal chow (without DHEA) and subjected to PH. All the rats were given a single intraperitoneal injection of $\left[{ }^{3} \mathrm{H}\right] \mathrm{dT}(1 \mu \mathrm{Ci} / \mathrm{g}$ body weight $) 1 \mathrm{~h}$ before sacrifice. Rats were sacrificed in groups of four at 20,26, 32 and $38 \mathrm{~h}$ after surgery.

To evaluate the effect of DHEA on mitogen-induced DNA synthesis, 16 rats were divided into four equal groups of four each. Group 1 and 2 were fed chow containing $0.025 \%$ ciprofibrate and $0.45 \%$ DHEA for 4 and 7 days, respectively. Groups 3 and 4 were fed diet containing only ciprofibrate ( 4 days) and normal chow, respectively. One $\mathrm{h}$ before sacrifice all rats were given a single intraperitoneal injection of $\left[{ }^{3} \mathrm{H}\right] \mathrm{dT}$ as described above.

\section{Hepatocyte labelling indices}

Portions of liver from all animals were fixed in $10 \%$ neutral buffered formalin and processed for light microscopy. Five-micron thick paraffin sections were routinely stained with haematoxylin and eosin ( $\mathrm{H} \& \mathrm{E}$ ) stain. In addition, deparaffinized $5 \mu$ m-thick sections were coated with Kodak NTB2 nuclear emulsion (Eastman Kodak Company, Rochester, NY) and incubated at $4^{\circ} \mathrm{C}$ in complete darkness. After 2 weeks slides were developed, fixed and stained with $\mathrm{H} \& \mathrm{E}$. Two thousand hepatocytes were counted from each animal to obtain the labelling index.

\section{RESULTS}

\section{DHEA effect on hepatocyte DNA synthesis after PH}

As expected, after $\mathrm{pH}$ the hepatocyte labelling index was highest at $20 \mathrm{~h}(35 \%)$, followed by a gradual decrease up to $32 \mathrm{~h}$ and a slight increase at $38 \mathrm{~h}$ (Table 1). Administration of DHEA in the diet for 7 days followed by PH resulted in a significant decrease in hepatocyte labelling indices at all time intervals examined. At $20 \mathrm{~h}$ after $\mathrm{PH}$ the labelling index in DHEA treated rats was $7.8 \%$, as compared to $35 \%$ in $\mathrm{PH}$ alone group.

\section{DHEA effect on ciprofibrate-induced DNA synthesis}

Body and liver weights and hepatocyte labelling indices data are presented in Table 2. Body weights in all groups were comparable. Liver weight in rats given ciprofibrate alone or 
Table 1. Effect of DHEA on hepatocyte DNA synthesis induced by partial hepatectomy"

\begin{tabular}{lcc}
\hline $\begin{array}{l}\text { Time after PH } \\
\text { (h) }\end{array}$ & $\begin{array}{c}\text { Labelling index (\%) } \\
\text { control group (no DHEA) }\end{array}$ & $\begin{array}{c}\text { Labelling index }(\%) \\
\text { DHEA treated }\end{array}$ \\
\hline 20 & $35.5 \pm 4.6^{\mathrm{bcc}}$ & $7.8 \pm 2.4$ \\
26 & $13.0 \pm 3.0^{\mathrm{h}}$ & $6.4 \pm 1.5$ \\
32 & $9.7 \pm 1.0^{\mathrm{h}}$ & $5.6 \pm 1.8$ \\
38 & $16.1 \pm 1.6^{\mathrm{b}}$ & $8.9 \pm 1.9$ \\
\hline
\end{tabular}

DHEA was fed in diet beginning 1 week before $\mathrm{PH}$ and continued until rats were sacrificed. $\mathrm{h} P<0.05$ to 0.001 . 'Mean \pm SEM of four rats.

ciprofibrate and DHEA increased by $37 \%$ and $46 \%$ after 4 days and $50 \%$ and $61 \%$ after 7 days, respectively. Interestingly, however, the hepatocyte labelling index in rats given ciprofibrate alone was significantly higher than in rats given ciprofibrate and DHEA. After 4 and 7 days of combined treatment the labelling index was $44 \%$ and $77 \%$ less, respectively, than in rats given ciprofibrate alone.

\section{DISCUSSION}

The results of this study clearly demonstrate that DHEA inhibits hepatocyte DNA synthesis after both PH and ciprofibrate administration. After PH administration DNA synthesis was at a maximum at $20 \mathrm{~h}$ followed by gradual decrease until $32 \mathrm{~h}$ and a slight increase at $38 \mathrm{~h}$ (a second wave). These findings are similar to those observed by others (Grisham 1968, Bucher et al. 1964). DHEA administration resulted in 4.5 -fold decrease in labelling index at $20 \mathrm{~h}$ and 1.7- to twofold decrease at other time points examined. The mechanism by which DHEA inhibits DNA synthesis after PH is not clear. It has been shown that replicative DNA synthesis is dependent on activation and interaction of several factors such as hormones, growth factors, cytokines and transcription factors (Bucher 1995, Fausto et al. 1995). It is not clear, at present, whether DHEA prevents priming of hepatocytes or interferes with growth factors.

Ciprofibrate, a potent peroxisome proliferator, like other members of peroxisome proliferators cause hepatomegaly, hepatic peroxisome proliferation along with induction of several cytosolic and peroxisome-associated enzymes (Rao \& Reddy 1991, Moody 1994). Hepatomegaly is secondary to both hyperplasia and hypertrophy of hepatocytes (Reddy \& Lalwani 1983). Results of the present study showed that there was a significant reduction in hepatocyte labelling index in animals treated with ciprofibrate and DHEA, when compared to rats treated with ciprofibrate alone. However, in both groups the liver weight was comparable and was $37 \%$ to $61 \%$ higher than in controls. These findings indicate that although liver cell

Table 2. Effect of DHEA on ciprofibrate induced DNA synthesis ${ }^{4}$

\begin{tabular}{lccc}
\hline Treatment & Body weight & Liver weight/100 g bwt & Labelling index (\%) \\
\hline Control & $132 \pm 3.9$ & $5.4 \pm 0.1$ & $0.30 \pm 0.03^{b}$ \\
Ciprofibrate for 4 days & $128 \pm 2.7$ & $7.9 \pm 0.2$ & $0.60 \pm 0.05^{\circ}$ \\
Ciprofibrate + DHEA for 4 days & $106 \pm 1.0$ & $7.4 \pm 0.2$ & $0.34 \pm 0.03$ \\
Ciprofibrate for 7 days & $129 \pm 1.0$ & $8.1 \pm 0.3$ & $1.32 \pm 0.24^{\circ}$ \\
Ciprofibrate + DHEA for 7 days & $117 \pm 1.3$ & $8.7 \pm 0.2$ & $0.30 \pm 0.06$ \\
\hline
\end{tabular}

"Ciprofibrate $(0.025 \%)$ and DHEA $(0.45 \%)$ were given in diet. ${ }^{b}$ Mean \pm SEM of four rats. ${ }^{c} P<0.05$. 
hyperplasia was inhibited, liver cell hypertrophy was not affected. We and others have previously demonstrated that DHEA is a peroxisome proliferator but an inhibitor of liver cell proliferation (Frenkel et al. 1990, Rao et al. 1992a,b). The mechanism by which DHEA inhibits liver cell proliferation is not clear. It has been shown that mitogen-induced liver cell hyperplasia, in general, is dependent on activation of tumour necrosis factor (TNF- $\alpha$ ) and not other growth factors or cytokines as in compensatory hyperplasia (Shinozuka et al. 1994, Ledda-Columbano et al. 1994). Interestingly, it appears, that peroxisome proliferator BR931-induced cell proliferation is not dependent on activation of TNF- $\alpha$ (Ohmura et al. 1995). We have not investigated expression of TNF- $\alpha$ or other growth factors in this study.

Cell proliferation is considered to play a major role in the development of tumours, as cell proliferation increases chances of converting DNA damage into mutations (Ames \& Gold 1990). However, this general principle may not be applicable to all systems. For example, tumour incidence is not high in small intestine where cell proliferation rate is very high and continuous. In the liver it has been clearly demonstrated that replicative DNA synthesis is conducive to the initiation and promotional phases of carcinogenesis; whereas, mitogeninduced liver-cell hyperplasia is ineffective in these phases of carcinogenesis (Farber 1991). In peroxisome proliferator induced hepatocarcinogenesis, the role of cell proliferation in tumour development remains controversial (Rao \& Reddy 1997).

The experimental model described here should serve as a useful tool to fully evaluate the role of cell proliferation in carcinogenesis in general and peroxisome proliferator induced hepatocarcinogenesis in particular. In the peroxisome proliferator hepatocarcinogenesis model, DHEA provides a unique opportunity to dissociate cell proliferation and peroxisome proliferation and examine their roles in carcinogenesis.

\section{ACKNOWLEDGEMENTS}

This research was supported by a Veterans Affairs Merit Review Grant.

\section{REFERENCES}

AmEs BN, Gold IS. (1990) Too many rodent carcinogens: mitogenesis increases mutagenesis. Science 249, 970.

BUCHER NLR. (1995) Liver regeneration. Then and now. Jirtle RL, ed. Liver Regeneration and Carcinogenesis, New York: Academic Press, 1.

Bucher NLR, Swaffield MN, DiTroia JF. (1964) The influence of age upon incorporation of thymidine-2- $\mathrm{C}^{14}$ into the DNA at regenerating rat liver. Cancer Res. 24, 509.

FARBER E. (1991) Hepatocyte proliferation in stepwise development of experimental liver cell cancer. Dig. Dis. Sci. 36, 973.

Fausto N, Laird AD, Webber EM. (1995) Role of growth factors and cytokines in hepatic regeneration. FASEB J. 9, 1527.

Frenkel RA, Slaughter CA, Orth K et al. (1990) Peroxisome proliferation and induction of peroxisomal enzymes in mouse and rat liver by dehydroepiandrosterone feeding. J. Steroid. 35, 333.

Grisham JW. (1968) Cellular proliferation in the liver. Fry RJM, Griem ML, Kirsten WH, eds. Recent Results in Cancer Research. Normal and Malignant Cell Growth. New York: Springer-Verlag, 28.

Hayashi F, Tamura H, Yamada, J, Kasai H, Suga T. (1994) Characteristics of hepatocarcinogenesis caused by dehydroepiandrosterone, a peroxisome proliferator, in male F-344 rats. Carcinogenesis $15,2215$.

Higgins GM, Anderson RM. (1931) Experimental pathology of liver. 1. Restoration of liver of white rat following partial surgical removal. Arch. Pathol. 12, 186.

Ledda-Columbano GM, Columbano A, Cannas A et al. (1994) Dexamethasone inhibits induction of liver tumor necrosis factor- $\alpha$ mRNA and liver growth induced by lead nitrate and ethylene dibromide. Am. J. Pathol. 145, 951. 
Moody DE. (1994) Peroxisome proliferation: an overview. Moody DE, ed. Peroxisome Proliferators. Unique Inducers of Drug-metabolizing Enzymes. Boca Raton: CRC Press, 1.

Nestler JE. (1995) DHEA: A coming of age. An. N. Y. Acad. Sci. 774, ix.

Ohmura T, Ledda-Columbano GM, Piga R et al. (1995) Hepatocyte proliferation induced by single dose of a peroxisome proliferator. Am. J. Pathol. 148, 185.

RAo MS, REDDY JK. (1991) Toxicological implications of peroxisome proliferation. Meeks R, Harrison S, Bull R, eds. Hepatotoxicology. Boca Raton: CRC Press, 621.

Rao MS, Revdy JK. (1997) Hepatocarcinogenesis of peroxisome proliferators. An. N. Y. Acad. Sci. 804, 573.

Rao MS, Subbarao V, Yeldandi AV, Reddy JK. (1992a) Hepatocarcinogenicity of dehydroepiandrosterone in the rat. Cancer Res. 52, 2977.

Rao MS, Musunuri S, Reddy JK. (1992b) Dehydroepiandrosterone induced peroxisome proliferation in the rat liver. Pathobiol. 60, 82.

REDDY JK, LALWANI ND. (1983) Carcinogenesis by hepatic peroxisome proliferators: evaluation of the risk of hypolipidemic drugs and industrial plasticizers to humans. CRC Rev. Toxicol. 12, 1.

Schwartz AG, Pashko LL. (1995) Mechanism of cancer preventive action of DHEA. An. N. Y. Acad. Sci. 774, 180.

Schwartz AG, Whitcomb JM, Nyce JW, Lewbart ML, Pashko LL. (1988) Dehydroepiandrosterone and structural analogs. A new class of cancer chemopreventive agents. Ad. Cancer Res. 51, 391.

Shinozuka H, Kubo Y, Katyal YS et al. (1994) Roles of growth factors and tumor necrosis factor- $\alpha$ on liver cell proliferation induced in rats by lead nitrate. Lab. Invest. 71, 35. 